Article

\title{
The Impact of Core Technological Capabilities of High-Tech Industry on Sustainable Competitive Advantage
}

\author{
Bing Feng ${ }^{1,2, *}$, Kaiyang Sun ${ }^{3}$, Min Chen ${ }^{4,5, *}$ and Tao Gao ${ }^{6}$ \\ 1 School of Economics and Management, Northwest University, Xi'an 710069, China \\ 2 School of Management, Yulin University, Yulin 719000, China \\ 3 School of Advertising, Marketing, Public Relations, Queensland University of Technology, \\ Brisbane QLD 4001, Australia; kaiyang.sun@hdr.qut.edu.au \\ 4 Academy of Financial Research, School of Business, Wenzhou University, Wenzhou 325035, China \\ 5 Department of Business Administration, National Central University, Taoyuan 32001, Taiwan \\ 6 School of Management, University of Toronto, Toronto, ON M5S 2E8, Canada; tony.gao@utoronto.ca \\ * Correspondence: zhouxiaowen@yulinu.edu.cn (B.F.); minchen@wzu.edu.cn (M.C.)
}

Received: 19 March 2020; Accepted: 4 April 2020; Published: 8 April 2020

check for updates

\begin{abstract}
The market competitiveness and sustainable operation of an enterprise are closely correlated with the support of high-tech core technologies in the enterprise. This study first discusses the basic knowledge of core competitiveness, introduces the components and evaluation methods of core competitiveness, and builds an evaluation index system for core competitiveness of high-tech enterprises. Then, the Analytic Hierarchy Process (AHP) is fully discussed, during which the steps, advantages, and disadvantages of the AHP evaluation method are introduced. Finally, the Fujian Province of China is taken as an example, the relevant data are collected and processed, the impact of indicators are analyzed, and a high-tech industry core technological capability analysis indicator system is built based on the AHP method. Thus, the influence of the core technological capabilities of the high-tech industry on the sustainable competitive advantage of the enterprise is obtained. This study puts forward suggestions for maintaining the competitiveness of high-tech industries, thereby improving the competitive advantage of enterprises and achieving the sustainable management of enterprises. The result finds that if the high-tech industries continue to carry out innovation and scientific research, enterprises will maintain their competitive advantages. In summary, exploring the impact of the core technological capabilities of high-tech industries on the sustainable competitive advantages of enterprises is greatly significant for improving their competitiveness and industrial status, which enables them to be invincible in a complex environment.
\end{abstract}

Keywords: high-tech industry; core technology; analytic hierarchy process; competitive advantage

\section{Introduction}

Innovation is recognized as an important driving force for economic development in many fields, which is also a vital way to enhance national strength and benefit people's lives. Throughout the historical development of the global society, the prosperity of economic development is often caused by the continuous improvement of the country's innovative capacity. For example, the first industrial revolution in the United Kingdom, which allowed manual operation to be replaced by machines, increased productivity rapidly, while great changes have also taken place in production and social relations. Then, the second industrial revolution, represented by electricity, turned the focus of society on scientific research and technological inventions and, this time, the United States and Germany became the front-runners. Subsequently, Japan also began to attach importance to technical issues, 
digesting, absorbing, and innovating technologies. Of course, China is not falling behind since it is working hard to develop new technologies gradually. Therefore, scientific and technological innovation and technological development have quietly coincided with the topic of the rise of the great powers with the trajectory of national scientific and technological innovation, which is also a key factor repeatedly emphasized by the government and enterprises in recent years [1].

Since its reform and opening up, China's economy has continued to grow, and tremendous changes have taken place in various fields. The core competitiveness of any enterprise is the source and basis for enterprises to obtain sustainable competitive advantages, especially for high-tech enterprises. The core technical capabilities of high-tech industries are the basis for maintaining the market competitiveness of enterprises. To achieve sustainable development, high-tech enterprises need to recognize and continuously improve their competitiveness. There is an urgent need to rely on the power of innovation to promote industrial upgrading and economic development all over the world. In the high-tech industry, core competitiveness is the foundation for the competitive advantages of a company's sustainable and stable operation. It is a series of complementary skills and knowledge that can be used by a company in a series of work processes, such as product development, production, and aftersales service, forming a competitive advantage that is not easily defeated [2]. If enterprises wish to occupy a certain share in the market, they need to constantly innovate their technology [3].

The competitive advantage of an enterprise is an important tool for companies in market competition, and the core technological capabilities of the high-tech industry are considered important tools for enterprise development. A new round of scientific and technological revolution is also in gestation. As a supply-side structural reform in China, the high-tech industry, which accelerates economic development and transformation, and promotes the deep integration of the global value chain, is also facing industrial reform. Especially in recent years, more innovation achievements and higher innovation ability make the high-tech industry gather more professionals and advanced ideas, which is a new economic growth point and development direction for any enterprise. The survival and development of an enterprise cannot be separated from the influence of the national and international environment. Enterprises hope to have sustainable competitive advantages. However, few enterprises can realize this. Besides, with the change in the living environment, the sustainable competitive development of enterprises is facing a severe test [4]. The core competence of the high-tech industry is the core competitiveness of enterprises in the market. At present, only a few enterprises are in the leading position in the industry. Only those enterprises that can seize the opportunity, implement reforms of the management system, introduce advanced technology first and carry out innovation research continuously can ensure certain competitive advantages in the long-term development process [5]. Quantitative evaluation of the sustainable competitive advantages of high-tech enterprises can deepen the understanding of the nature of high-tech enterprises further, which is conducive to enriching and improving the current management theories of high-tech enterprises.

The competitive advantage of an enterprise is an important tool in the market competition, while the core technological capability of the high-tech industry is considered to be an important tool for the development of an enterprise. In this study, analyzing the sustainable competitive advantages of high-tech enterprises, on the one hand, will help business managers to improve their business level and promote the healthy, rapid, and sustainable development of high-tech enterprises. On the other hand, studying the sustainable competitive advantages of high-tech enterprises has important practical significance for the sustainable development of high-tech enterprises and the healthy and sustainable development of the national economy. In this paper, from the perspective of enhancing the market competitiveness of an enterprise, an index system is constructed by an Analytic Hierarchy Process (AHP), and then the impact of the core technological capability of the high-tech industry on the sustainable competitive advantage of an enterprise is analyzed. By constructing an evaluation model of the core competitiveness of high-tech enterprises, this study hopes to provide a reference for the future development of the enterprise. To achieve the sustainable competitive advantage of high-tech enterprises, only through a continuous reconstruction of continuous competitive advantages, 
the establishment of a "continuum" of interconnected or successive competitive advantages, and the formation of a virtuous cycle of continuous competitive advantages, can the true continuity of competitive advantages be achieved.

\section{Literature Review}

In the long-term development process, the enterprise's ability gradually transforms from single production capacity to technological innovation capacity, market development capacity, organizational management capacity, organizational learning capacity, coordination, combination capacity, research and development capacity, and strategic management capacity. The core capability of an enterprise is the inevitable result of training, integrating, and improving its abilities.

Grupp (1997) and Roper and Love (1999) explained the enterprise competition in terms of innovation efficiency, extended the determinants of innovation from research and development to technology transfer and network effects, thereby expanded the standard Schumpeter analysis. After testing, it was found that research and development, technology transfer, and networking were substitutes in the innovation process, while the latter two intensities were particularly important to improve the degree of innovation [6,7]. Edvinsson et al. (2014) believed that the constituent elements of innovation were very important contents for stakeholders in the process of management and development. They discussed the constituent elements of innovation from the perspective of knowledge and proposed a toolkit based on performance measurement ideas and implementation processes, which could better balance the relationship between enterprise competitiveness and innovation in the development environment. However, they did not make an in-depth study on the balance in the management and development environment [8]. Moreover, compared with enterprises located in agglomerations or industrial clusters, enterprises in the periphery have benefited less from local spillovers. Grillitsch and Nilsson (2015) held that innovation largely depended on the ability and opportunity of enterprises to acquire external knowledge. Compared with the enterprises in the cluster area, the innovative enterprises on the periphery of the industrial cluster area lacked knowledge spillover, but they could make up for this defect through cooperation [9]. Prasad et al. (2018) believed that industry 4.0 and environmentally sustainable manufacturing could be integrated to promote environmentally sustainable manufacturing. However, they only emphasized the challenges and opportunities brought by this process, without further study of the key factors [10]. Research shows that the research and development funding (RD) investment of the high-tech industry has a positive impact on economic growth, while RD personnel investment harms all regions and the entire sample. New product development funding has a positive impact on economic growth, while the number of patent applications has a significant positive impact on economic growth. In general, high-tech industry innovation factors can effectively promote economic growth; however, it is necessary to note the accuracy of factor inputs, improve the efficiency of factor use, and focus on regional differences in policies. Furthermore, the innovation models and efficiency of high-tech industries are very different. Such differences not only are reflected in the efficiency of technological innovation in different industries, but also lead to uneven levels of technological innovation among various industries.

In addition to studying the impact of technology innovation on business operation and economic development, some scholars considered the external environmental factors besides internal innovative technology and comprehensively, and comprehensively analyzed their impact on the survival and development of enterprises. Thus, there are more studies on the comprehensive planning of corporate development strategies using the SWOT analysis model. Tang et al. (2012) thought that the expansion of the company's business would be affected by environmental, material and other factors, so the SWOT method of entropy was used to eliminate the uncertainty among respondents, thereby providing a reliable and reasonable basis for decision-making. However, they only evaluated the key factors of entering the international market and did not further analyze the core competence [11]. Abdel-Basset et al. (2018) held that the most widely used technology in strategic planning was SWOT analysis, and AHP could quantify these strengths, weaknesses, opportunities, and threats, 
thus verifying its model. AHP weights and ranks quantitative and qualitative elements through a comparison matrix to determine them. However, the analysis of the impact on the core technological capability of the enterprise is ineffective [12].

In recent years, more scholars have begun to pay attention to the impact of technological innovation on the maintenance of the market competitiveness of enterprises based on in-depth research into enterprise competitiveness. Della Corte (2018) focused on the relationship between cooperation and innovation and its impact on competitive advantage. However, he only described the source of competitive advantage and did not study the impact of these competitive advantages [13]. Čirjevskis (2019) discussed the role of dynamic capabilities in the acquirer's business model innovation in the merger and acquisition (M \& A) of technologically advanced companies. Through the examples of Harman, Linkedln, Samsung, and Microsoft, the dynamic capabilities were qualitatively analyzed. However, the amount of data was small, and there was a lack of reliability in the analysis of the original data, especially in the discussion of core technological capabilities [14].

As an important industry in various countries, the development of high-tech industries has attracted attention in the process of social and economic development. At the same time, the core technological capabilities of high-tech industries have become important tools for enterprises in market competition, whereas most of the existing literature starts with the analysis of the core competence of the enterprise, and there is no more in-depth analysis of the core technological competence. Meanwhile, when studying the influence of the core competence on the competition of the enterprise, SWOT analysis is used, and the factors cannot be quantitatively analyzed. Therefore, this paper uses improved AHP to quantify the core technological competence of the high-tech industry. Consequently, the influence of sustainable competitive advantage is discussed, making the enterprise aware of the importance of core technological capability. Thus, the enterprise can obtain considerable economic benefits in the competition, and make itself have a sustainable competitive advantage.

\section{Methods and Experiments}

\subsection{Analytic Hierarchy Process}

AHP is a systematic evaluation and a combination of qualitative and quantitative evaluation methods. It continuously subdivides all factors that affect the evaluation results and evaluates the targets hierarchically. Qualitatively, combining with quantitative means, it determines the weight of each indicator based on subjective evaluation $[15,16]$. Therefore, AHP is a multi-criteria decision-making method for quantitative analysis of qualitative problems. It has the advantages of simplicity, flexibility, and practicality. It can divide various factors related to the evaluation system into mutually restricted and interconnected leveled structures, making them organized. When dealing with both quantitative and qualitative factors, AHP has obvious advantages $[17,18]$. The steps of the AHP are shown in Figure 1.

Constructing a hierarchical structure is mainly done in order to divide the goals of decision-making, the factors to be considered, and the objects of decision-making into the highest level, middle level, and bottom level according to their mutual relationship $[19,20]$. Then, a hierarchical structure diagram is plotted. The top layer is mainly the purpose of the decision and the problem to be solved. The middle layer is the factors that need to be considered and the criteria for the decision. The bottom layer is the alternative when making the decision. For the two adjacent layers, the upper layer is also called the target layer, and the bottom layer is the factor layer [21,22], and Figure 2 shows its model. 


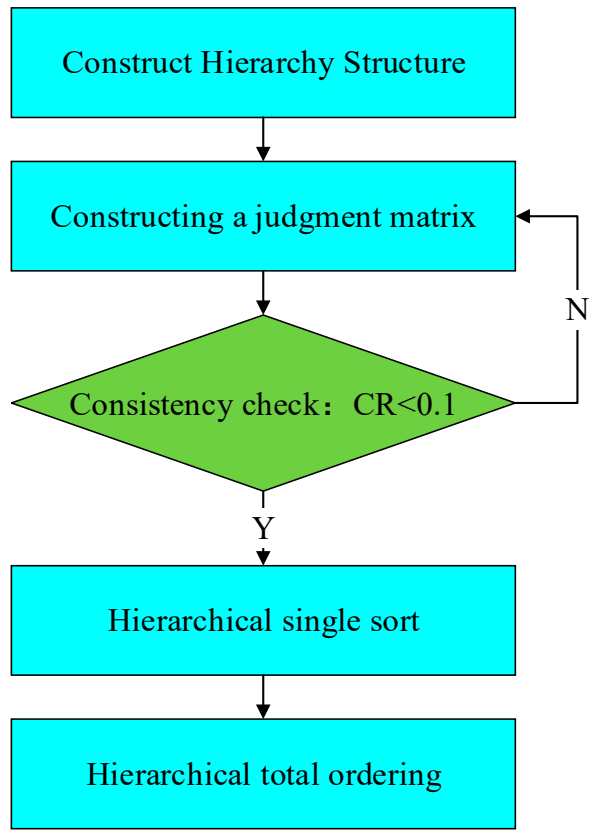

Figure 1. Steps of Analytic Hierarchy Process (AHP).

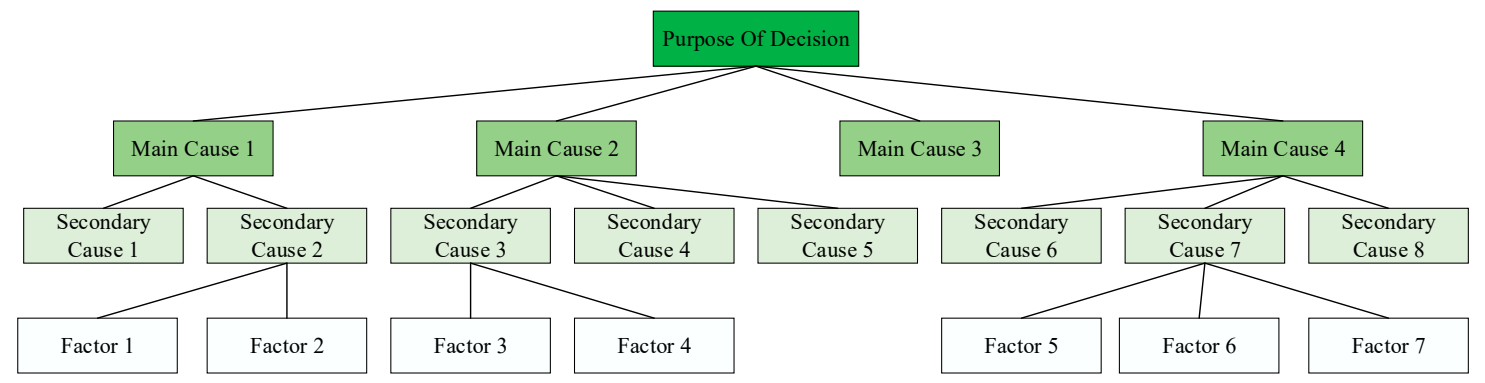

Figure 2. Hierarchical model.

After constructing the hierarchical model, a judgment matrix needs to be constructed. This is to compare all factors separately and to use relative scales to minimize the difficulty of comparing factors with different properties, thereby improving the accuracy [23,24]. The judgment matrix is a comparison of the relative importance of all factors in this layer against a certain factor in the previous layer. The elements $\mathrm{a}_{\mathrm{ij}}$ of the judgment matrix are given on a 1-9 scale, as shown in Table 1.

Table 1. The judgment of the scale of matrix elements $\mathrm{a}_{\mathrm{ij}}$.

\begin{tabular}{cc}
\hline Scaling & Meaning \\
\hline 1 & Through comparison, the two factors are of equal importance. \\
3 & Through comparison, one factor is slightly more important than the other factor. \\
7 & Through comparison, one factor is more important than the other factor. \\
9 & Through comparison, one factor is strongly more important than the other factor. \\
$2,4,6,8$ & Through comparison, one factor is extremely more important than the other factor. \\
Reciprocal & $\mathrm{a}_{\mathrm{ij}}$ is determined by comparing factors $\mathrm{i}$ and $\mathrm{j}$, and the matrix element $\mathrm{a}_{\mathrm{ji}}=1 / \mathrm{a}_{\mathrm{ij}}$ is determined \\
by comparing factors $\mathrm{j}$ and $\mathrm{i}$.
\end{tabular}

Therefore, it is assumed that there is an element that can obtain the corresponding judgment matrix $C=\left(C_{i j}\right)_{n x m}$, where $C_{i j}$ represents the importance of factors $i$ and $j$ relative to the target value. 
Afterwards, the consistency of the judgment matrix needs to be checked. This is because the judgment matrix previously constructed may not be consistent due to the errors of the evaluator or the lack of relevant knowledge $[25,26]$. Therefore, the judgment matrix needs to be tested for consistency. The test process uses the change in the characteristic root of the judgment matrix to check the consistency of the judgment matrix. Assuming that the Eigenvector W and Eigen root $\lambda$ of the judgment matrix need to be calculated by the following equation:

$$
M_{i}=\prod_{j=1}^{n} a_{i j}, i=1,2, \cdots, n
$$

where $\mathrm{M}_{\mathrm{i}}$ represents the product of the elements of each row of the judgment matrix. The $\mathrm{n}$-th root of each row of elements is found according to the product $[27,28]$, as shown in Equation (2):

$$
\bar{W}_{i}=\sqrt[n]{M_{i}}
$$

Based on the above equation, the vector is normalized further, as shown in Equation (3):

$$
W_{i}=\frac{\bar{W}}{\sum_{j=1}^{n} \bar{W}_{j}}
$$

In the above equation, $\mathrm{W}=\left[\mathrm{W}_{1}, \mathrm{~W}_{2}, \ldots, \mathrm{W}_{\mathrm{n}}\right]^{\mathrm{T}}$ is the Eigenvector of the judgment matrix. Then, it is necessary to calculate the maximum Eigenvalue of this judgment matrix, as shown in Equation (4):

$$
\lambda_{\max }=\sum_{i=1}^{n} \frac{(A W)_{t}}{n W_{i}}
$$

where $(\mathrm{AW})_{\mathrm{i}}$ represents the $\mathrm{i}$-th element of the vector AW. Its consistency also needs to be judged by Equation (5):

$$
C I=\frac{\lambda_{\max }-n}{n-1}
$$

In the above equation, the smaller the $\mathrm{CI}$ value is, the better the degree of consistency is, otherwise, the worse the degree of consistency is [29,30]. In addition, the random consistency ratio (CR) is used to determine whether the matrix has satisfactory consistency, which is obtained by Equation (6):

$$
C R=\frac{C I}{R I}<0.10
$$

After satisfying Equation (6), it can be determined that the constructed judgment matrix has satisfactory consistency. The value of the Average Random Consistency Index (RI) will vary with the order of the matrix. It is generally believed that the judgment matrix of order 1,2 must have complete consistency, and the RI value is 0.00 . Hence, there is no need to calculate CR, and the RI for the 9th order matrix is 1.45 [31,32].

The AHP method is widely used in the analysis of influencing factors. However, principal component analyses, entropy weight, and SWOT analyses are also used. Nevertheless, in the end, considering the need to constantly refine the influencing factors, the AHP method combining the quantitative and qualitative analysis is adopted to analyze the influencing situation, thereby better understanding the influencing situation. The AHP method is used to transform the complex relationship of each layer into a more hierarchical index system, and then calculate the influence weight of different indices on its sustainable competitive advantage, thus making the evaluation more objective. 


\subsection{Results of the Establishment of the Indicator System}

In the growth and development of high-tech enterprises, the description of the company's core competitiveness mainly starts from the following four dimensions [33]. First, the core competitiveness is represented by the company's technological competitiveness, which can help the enterprises adapt to changes in the external environment, use and grasp opportunities, reduce the threat of external competitors, and create value for the development of enterprises. Second, such technological competitiveness is limited to a very small number of existing competitors or potential competitors. Third, this kind of scientific and technological competitiveness is difficult to imitate by other enterprises. Fourth, the core competitiveness of an enterprise adapts to its development strategy, so other enterprises cannot simply follow [34]. Therefore, the core competitiveness of high-tech companies mainly includes scientific and technological innovation capabilities, scientific and technological human capital, scientific and technological financial capital, organizational coordination and integration capabilities, corporate external influence capabilities, and adaptability [35].

Among them, the key to the core competitiveness of high-tech companies lies in their technological innovation capabilities. The reason is that, with the advent of the era of the knowledge economy, the competition between high-tech enterprises depends on scientific and technological resources, and the focus of the competition is the result of various scientific and technological activities [36]. Therefore, technological innovation has become a strategic core for high-tech enterprises to occupy the commanding economic heights of the 21st century [37,38]. A sound scientific and technological innovation system can motivate the sustainable development of enterprises, and the construction of an enterprise's technological innovation system is directly related to the progress and quality of the national innovation system construction. As an organism that promotes technological innovation in an enterprise, the establishment of an effective corporate technological innovation system is a guarantee for improving corporate innovation capabilities.

Generally, among the same industry and companies producing similar products, there are some general and universal technologies, which are mainly manifested in the form of technical specifications, standard processes, and general equipment. Such a general technological capability is commonly owned by all enterprises, while the core technological capabilities are different, which are unique to each high-tech company [39]. The core technological capabilities of each successful high-tech company have their unique features and are not easily imitated by other companies or potential competitors. This also gives the company a place in the industry. At the same time, this high-tech enterprise with core technological capabilities will also ensure that core technologies are not intentionally or unintentionally leaked by others by applying for patents and implementing technical confidentiality. Therefore, if companies in the high-tech industry wish to stabilize their position in the industry, they will not simply imitate other companies but work hard to develop their core technological capabilities [40].

In addition to the unique core technological capabilities of each company, it is also necessary to see whether the core technological capabilities are the product requirements of good quality, reasonable price, and adequate aftersales service required in the market. Only if the company's core technological capability is the key to a certain aspect of the technology can the company produce products that are different from or even better than other companies, thereby gaining a larger market share [41].

The core technological capabilities of an enterprise are formed after a long period of study and experimentation in the company's continuous development. They are often combined with the accumulation of experience, which usually costs a higher price; therefore, they are considered relatively stable $[42,43]$. When the external environment changes, such stability is manifested as inertia more often, which is also called rigidity. In the continuous development of the high-tech industry, it is necessary to continue to promote reform and innovation. Only continuous research and new developed products can provide a larger market share [44-46]. However, at this time, core technological capabilities may hinder product innovation because of its rigidity.

Therefore, based on the analysis of the relevant content of the core competence of the enterprise, through the necessary research and induction, a three-level comprehensive evaluation index system of 
the core technological competence is proposed [47,48]. The index system is studied in detail, and Table 2 is obtained.

Table 2. Indicator system.

\begin{tabular}{|c|c|c|}
\hline \multirow{17}{*}{$\begin{array}{l}\text { Core technological } \\
\text { capability }(\mathrm{A})\end{array}$} & \multirow{6}{*}{$\begin{array}{l}\text { Technological } \\
\text { innovation } \\
\text { capability (B1) }\end{array}$} & The proportion of R \& D personnel in total (C1) \\
\hline & & $\begin{array}{c}\text { The proportion of } \mathrm{R} \& \mathrm{D} \text { personnel with a master's degree and } \\
\text { doctor's degree (C2) }\end{array}$ \\
\hline & & $\begin{array}{c}\text { The proportion of } \mathrm{R} \& \mathrm{D} \text { personnel with senior professional titles } \\
\text { among R \& D personnel (C3) }\end{array}$ \\
\hline & & The proportion of R \& D investment in total revenue (C4) \\
\hline & & $\begin{array}{l}\text { The proportion of national scientific research funds in total } \\
\text { income (C5) }\end{array}$ \\
\hline & & The proportion of laboratory assets in total assets (C6) \\
\hline & \multirow{6}{*}{$\begin{array}{l}\text { The productivity of } \\
\text { the science and } \\
\text { technology } \\
\text { industry (B2) }\end{array}$} & $\begin{array}{c}\text { The proportion of total industrial investment in total } \\
\text { investment (C7) }\end{array}$ \\
\hline & & The proportion of industrial income to total income (C8) \\
\hline & & The proportion of project contract revenue to total revenue (C9) \\
\hline & & Market share of main products $(\mathrm{C} 10)$ \\
\hline & & The sales profit margin of main products (C11) \\
\hline & & Main production equipment level (C12) \\
\hline & \multirow{5}{*}{$\begin{array}{l}\text { The production } \\
\text { capacity of high-tech } \\
\text { products (B3) }\end{array}$} & $\begin{array}{l}\text { The annual output rate of scientific and technological } \\
\text { achievements (C13) }\end{array}$ \\
\hline & & $\begin{array}{c}\text { The annual award for scientific and technological } \\
\text { achievements (C14) }\end{array}$ \\
\hline & & Number of patent approvals per year (C15) \\
\hline & & Transfer of scientific and technological achievements (C16) \\
\hline & & The proportion of technical income (C17) \\
\hline
\end{tabular}

\subsection{Results of $A H P$}

According to the above indicators, a hierarchical structure model can be constructed, including a target layer, a middle layer, and a bottom layer, as shown in Figure 3.

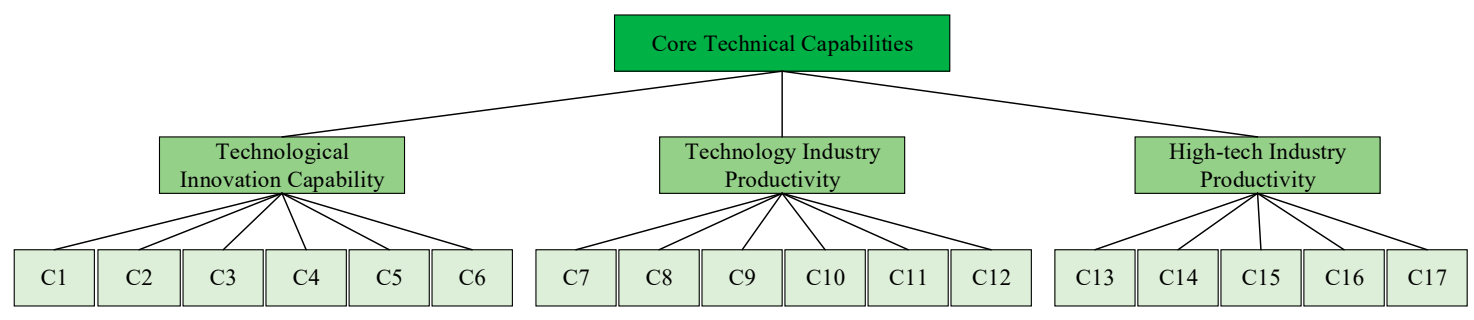

Figure 3. The core technological capability of the high-tech industry.

Figure 3 shows that there are three secondary indicators and 17 tertiary indicators, and then the weights of these indicators are evaluated. When calculating the weight, its importance is judged by the statistical opinions of relevant experts in the Delphi method [49-51]. The method is to sort out, summarize, and count the problems after obtaining the experts' opinions. Then, these are fed back to the experts anonymously, until finally a consensus with the experts is reached [52]. The judgment matrix is calculated by yaahp software to determine whether the consistency ratios are less than 0.1 . Therefore, the evaluation results of the second-level indicators of the technological capabilities of the high-tech industry are shown in Table 3. 
Table 3. Evaluation results of second-level indicators.

\begin{tabular}{ccccc}
\hline Second-Level Indicators & B1 & B2 & B3 & Wi \\
\hline B1 & 1.00 & 1.00 & 2.00 & 0.3873 \\
B2 & 1.00 & 1.00 & 1.00 & 0.3107 \\
B3 & 0.50 & 1.00 & 1.00 & 0.302 \\
\hline
\end{tabular}

On this basis, the weight information of three-level indicators is shown in Table 4.

Table 4. Evaluation results of the third-level indicators on the uniqueness.

\begin{tabular}{|c|c|c|c|c|}
\hline First-Level Indicators & Second-Level Indicators & Weight & Third-Level Indicators & Weigh \\
\hline \multirow{3}{*}{$\begin{array}{l}\text { Core technological } \\
\text { capability }(\mathrm{A})\end{array}$} & $\begin{array}{l}\text { Technological innovation } \\
\text { capability (B1) }\end{array}$ & 0.3373 & $\begin{array}{l}\text { C1 } \\
\text { C2 } \\
\text { C3 } \\
\text { C4 } \\
\text { C5 } \\
\text { C6 }\end{array}$ & $\begin{array}{l}0.23 \\
0.14 \\
0.12 \\
0.23 \\
0.19 \\
0.09\end{array}$ \\
\hline & $\begin{array}{l}\text { The productivity of the } \\
\text { science and technology } \\
\text { industry (B2) }\end{array}$ & 0.3607 & $\begin{array}{l}\text { C7 } \\
\text { C8 } \\
\text { C9 } \\
\text { C10 } \\
\text { C11 } \\
\text { C12 }\end{array}$ & $\begin{array}{l}0.20 \\
0.19 \\
0.16 \\
0.17 \\
0.16 \\
0.12\end{array}$ \\
\hline & $\begin{array}{l}\text { Output capacity of } \\
\text { high-tech products (B3) }\end{array}$ & 0.302 & $\begin{array}{l}\text { C13 } \\
\text { C14 } \\
\text { C15 } \\
\text { C16 } \\
\text { C17 }\end{array}$ & $\begin{array}{l}0.18 \\
0.19 \\
0.18 \\
0.21 \\
0.24\end{array}$ \\
\hline
\end{tabular}

Table 3 shows that the consistency ratio is 0.0170 and the maximum characteristic root is 4.0416 . However, it can be seen from Table 4 that the productivity of the science and technology industry has an impact on the core technological capability, accounting for 0.3607. Generally speaking, the productivity of the science and technology industry is essential for enterprises to have a certain level of competitiveness.

\subsection{Data Collection and Processing}

In terms of obtaining competitive evaluation data, the data provided by government departments are usually the best choice, followed by statements published by listed companies, survey data from social intermediaries, and then self-reported data by enterprises. The collection of quantitative index data of innovation clusters is based on high-tech industries, which reflects the overall status of high-tech innovation clusters. Eastern China has obvious advantages in absorbing foreign capital and self-accumulation due to its unique economic basic conditions. It is the main bloc of China's high-tech industry. In recent years, Fujian Province has performed poorly in all the Eastern provinces; also, its high-tech industry foundation and innovation capacity were weaker and lower than those in the coastal provinces. At present, Fujian Province is in a transition period from traditional industries to modern industries. However, its high-tech industry base and innovation ability are not ideal. Improving the innovation ability of high-tech industries in Fujian Province is a way of transforming economic development. Therefore, this study chooses Fujian Province as the research object. In this study, by querying and processing the data obtained from China Statistical Yearbook, Fujian Statistical Bureau's 2015-2018 Statistical Yearbook, and related website data, Table 5 is obtained. 
Table 5. Data processing.

\begin{tabular}{ccccc}
\hline Third-Level Indicators & $\mathbf{2 0 1 5}$ & $\mathbf{2 0 1 6}$ & $\mathbf{2 0 1 7}$ & $\mathbf{2 0 1 8}$ \\
\hline C1 & 0.17 & 0.21 & 0.33 & 0.33 \\
C2 & 0.31 & 0.28 & 0.33 & 0.33 \\
C3 & 0.29 & 0.27 & 0.31 & 0.38 \\
C4 & 0.11 & 0.15 & 0.18 & 0.25 \\
C5 & 0.24 & 0.26 & 0.28 & 0.33 \\
C6 & 0.34 & 0.36 & 0.31 & 0.39 \\
C7 & 0.13 & 0.15 & 0.33 & 0.34 \\
C8 & 0.25 & 0.29 & 0.25 & 0.33 \\
C9 & 0.17 & 0.22 & 0.37 & 0.38 \\
C10 & 0.12 & 0.21 & 0.31 & 0.31 \\
C11 & 0.18 & 0.22 & 0.31 & 0.29 \\
C12 & 0.16 & 0.15 & 0.29 & 0.28 \\
C13 & 0.17 & 0.17 & 0.31 & 0.31 \\
C14 & 0.11 & 0.18 & 0.33 & 0.33 \\
C15 & 0.12 & 0.22 & 0.28 & 0.30 \\
C16 & 0.13 & 0.21 & 0.27 & 0.29 \\
C17 & 0.11 & 0.19 & 0.33 & 0.31 \\
\hline
\end{tabular}

\section{Results and Discussion}

The results of second-level indicators are obtained, as shown in Figure 4.

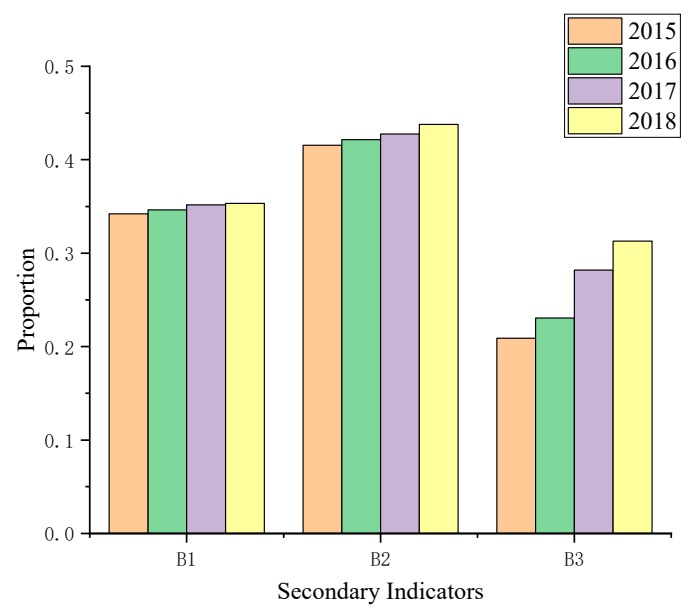

Figure 4. Comparison of second-level indicators.

As shown in Figure 4, the three second-level indicators have increased from 2015 to 2018, in which the key indicator B2 has grown significantly faster and B1 has grown more slowly.

The above results suggest that the productivity of the science and technology industry has the greatest impact on the core technological capacity. For the B1 index, the growth rate reached 1.3\% in 2016, but only $0.5 \%$ in 2018. This shows that the growth rate has slowed down. For the B2 index, the growth trend has been upward from 2016 to 2018. For B3, the growth rate is obvious. Therefore, it is considered that the productivity of the science and technology industry can improve the ability of technological innovation to a certain extent, and the ability of product output can also promote the development of technological innovation ability, which plays a great role in maintaining the sustainable competitive advantage of enterprises.

Enterprises have a certain technological innovation capability, which is an important source of competitive advantage. This is hard to imitate by other enterprises. However, in the information age, the number of competitors is increasing, their innovative products are constantly being surpassed, and the core technology expertise has a certain rigidity, so it is difficult to maintain for a long time. 
The sustainable competitive advantage of an enterprise will also change with the change in the external environment, which may make the original competitive advantage of an enterprise be transformed into an obstacle or restriction factor of its development. Hence, an enterprise needs to constantly improve its ability to cope with changes in the environment, and constantly reconstruct its competitive advantage to obtain a real, sustainable competitive advantage, as shown in Figure 5.

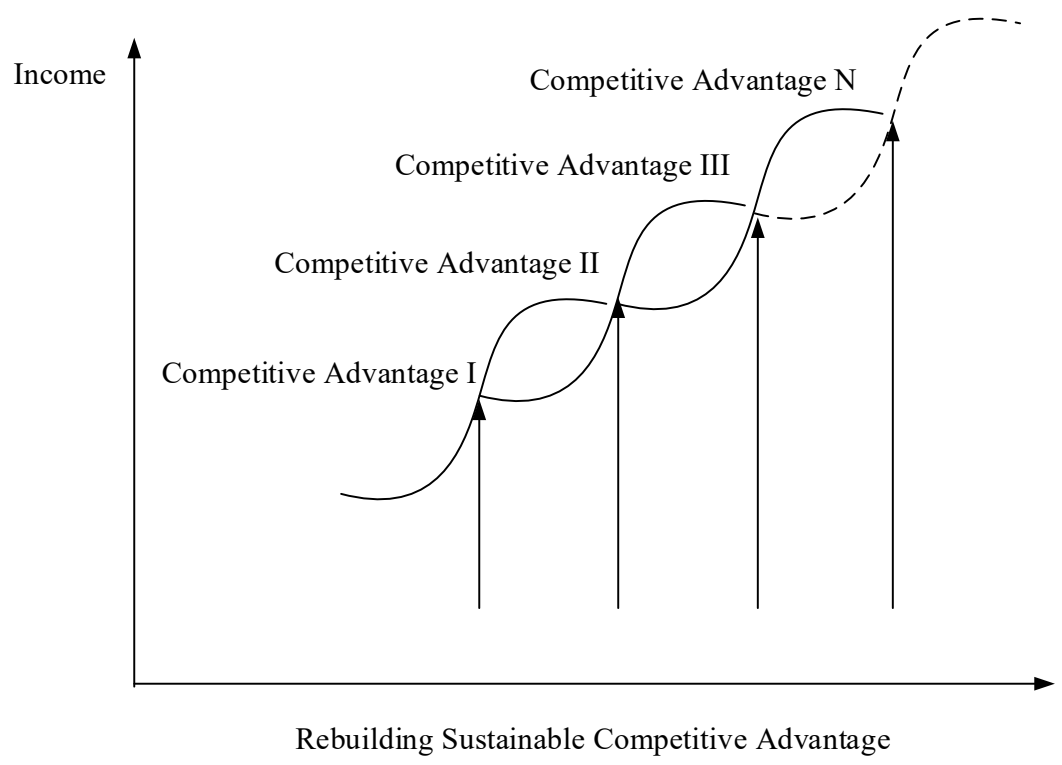

Figure 5. The sustainable competitive advantage of enterprises.

Therefore, according to Figure 5, under the changing market environment, it is necessary to constantly adjust the competitive advantages of enterprises to adapt to the changing external environment, and then implement the corresponding market strategy to obtain higher profits. However, in the research, it is found that even if the core technology ability is stronger and the industrial productivity and the product production ability are stronger, the enterprise itself needs a set of better management and decision-making systems, thereby making the internal resources, ability, and technology of the enterprise match, and jointly build the sustainable competitiveness of the enterprise.

To summarize, the coordinated development of technological innovation ability, the productivity of the science and technology industry, and the output ability of high-tech products also need to consider the market environment faced by enterprises. Only by constantly adjusting the competitive advantage of enterprises and adapting to the changing external environment can the sustainable competitive advantage of enterprises be helped. The conclusion of this paper further confirms that the research and development capital investment of the high-tech industry has a positive impact on economic growth, and the new product development capital has a positive impact on economic growth, which is consistent with the results of previous studies. In addition, this paper explores the sustainable competitive advantage of enterprises, which proves that the sustainable competitiveness of enterprises adapts to the industry field and has individual differences. In addition, the internal management and decision-making system of the enterprise also needs to match the ability of the enterprise, thereby making the enterprise have enough competitive advantage in the market and ensuring the economic benefits of the enterprise.

\section{Conclusions}

As long as an enterprise can maintain an operating performance higher than the average level of its industry for a long time, it can be recognized that the enterprise has a sustainable competitive advantage. If an enterprise can raise the idea of sustainable development to strategic management, 
and fully penetrate all fields of the enterprise, it can bring the following sustainable competitive advantages to the enterprise: (1) promote innovation. Technological innovation often creates miracles, so that the cost is greatly reduced and the function is greatly enhanced. (2) Reduce the production cost of the enterprise. With the increasingly strict requirements of the relevant national laws and regulations for the sustainable development of enterprises, the earlier the enterprises implement the sustainable development strategy, the greater the benefits and competitive advantages they get from it. (3) Obtain new capital channels. The sustainable development strategy can minimize the production costs of enterprises, and reduce the secondary treatment expenses related to environmental protection, thereby acquiring more funds for the development of enterprises.

This study analyzes the core technological capabilities of the high-tech industry by using the AHP method, constructs an indicator system, uses the uniqueness, criticality, and rigidity of the core technology as the second-level indicators, and continues to refine them into 17 third-level indicators. After constructing the indicator system, by taking Fujian Province as an example, the relevant data are collected and processed to analyze the impact of the indicators, thereby obtaining the promoting or suppressing impact of core technological capabilities of the high-tech industry on the sustainable competitive advantages of enterprises. Eventually, the corresponding suggestions are provided. According to the relevant literature and the research, it is known that core technological capability, technology innovation capability, technology industry productivity, and high-tech product output capability enable enterprises to maintain a certain sustainable competitive advantage. However, the external environment and internal management decision-making faced by the enterprise are also very important. Only when the enterprise continuously adjusts its competitive advantage can it maintain a sustainable competitive advantage and have the advantage of sustainable competition.

The AHP method also has certain shortcomings in its application. It can only choose an optimal strategy in a given list of strategies. Secondly, the AHP method needs to show consistency when performing the multi-layer comparison. In comparison, if the requirements of the consistency index are not met, the AHP method does not take effect. Finally, the AHP method requires the Eigenvalues of the matrix. However, in the AHP method, the average method is often used (arithmetic, geometric, and coordinated average) to find the Eigenvalues, which has systematic errors for some ill-conditioned matrices. Moreover, when using the AHP method to analyze its influence, the experts may be affected by subjective factors when scoring the indicators. Therefore, we consider the possibility for combining the AHP method with other more objective entropy weight analysis methods, thus improving the accuracy of the research. Therefore, exploring the impact of the core technological capabilities of high-tech industries on sustainable competitive advantage is of great significance to improve the competitiveness of enterprises and the status of the industry, as well as making enterprises invincible in a complex environment. Meanwhile, it provides more ideas for enterprises to research and innovate technologies. Since this study does not analyze the core technology investment and incubation environment from the perspective of the research process, the research conclusions have certain limitations. Therefore, in subsequent research, the discussion will be refined continuously, and the impact of the core technology of the high-tech industry on the sustainable competitive advantage of enterprises will be explored from a more comprehensive perspective.

Author Contributions: Conceptualization, B.F. and M.C.; methodology, M.C.; software, K.S.; validation, M.C. and T.G.; formal analysis, B.F.; investigation, M.C.; writing-original draft preparation, B.F.; writing-review and editing, M.C.; visualization, K.S.; All authors have read and agreed to the published version of the manuscript.

Funding: This research was funded by [Project of National Nature Science Foundation of China Titled "Research on the Mechanism of the Impact of Chinese Domestic VC Cross-border Investment on Innovation of Chinese Domestic Enterprises, 2020-2023"] grant number [71962033], [Youth Fund Project of Humanities and Social Science Research of Ministry of Education Titled "Research on Dynamic Influence Mechanisms of the Equity Participation of Government Venture Capital Guiding Funds on Venture Capital Firm's Network Position, 2017-2020"] grant number [17YJC630023], [Project of Social Sciences Circles' Union of Yulin City Titled “Research on Influencing Factors of Private Capital Participating in Venture Capital Investment of Small and Medium-sized Enterprises, 2017-2018"] grant number [YLSKGH2017-20], [Research Startup Project of Advanced Talents of Yulin University Titled "Research on the Influences of Government Venture Capital Guiding Funds on Later Financing of Venture 
Enterprises"] grant number [Grant No. 17GK02], [China Postdoctoral Science Foundation funded project] grant number [Grant No.2018M633560] and [Shaanxi Postdoctoral Foundation funded project Titled "Study of the Innovation Effect of State-owned Corporate Venture Capital and Its Mechanism"].

Conflicts of Interest: The authors declare no conflict of interest.

\section{References}

1. MacDonald, A.; Clarke, A.; Huang, L.; Seitanidi, M.M. Partner strategic capabilities for capturing value from sustainability-focused multi-stakeholder partnerships. Sustainability 2019, 11, 557. [CrossRef]

2. Boadu, F.; Xie, Y.; Du, Y.-F.; Dwomo-Fokuo, E. MNEs subsidiary training and development and firm innovative performance: The moderating effects of tacit and explicit knowledge received from headquarters. Sustainability 2018, 10, 4208. [CrossRef]

3. Kim, H.; Park, S.Y.; Joh, W.I.L. A study on technology development performance and technology commercialization performance according to the technology development capability of smes focusing on a comparative analysis of technology business groups. JOItmC 2019, 5, 65. [CrossRef]

4. Saura, J.R.; Debasa, F.; Reyes-Menendez, A. Does user generated content characterize millennials' generation behavior? Discussing the relation between SNS and open innovation. JOItmC 2019, 5, 96. [CrossRef]

5. Sutopo, W.; Astuti, R.W.; Suryandari, R.T. Accelerating a technology commercialization; with a discussion on the relation between technology transfer efficiency and open innovation. JOItmC 2019, 5, 95. [CrossRef]

6. Grupp, H. External effects as a microeconomic determinant of innovation efficiency. Int. J. Econ. Bus. 1997, 4, 173-188. [CrossRef]

7. Roper, S.; Love, J.H. The determinants of innovation: R \& D, technology transfer and networking effects. Rev. Ind. Organ. 1999, 15, 43-64.

8. Edvinsson, L.; Dvir, R.; Roth, N.; Pasher, E. Innovations: The new unit of analysis in the knowledge era: The quest and context for innovation efficiency and management of IC. J. Intellect. Cap. 2004, 5, 40-58. [CrossRef]

9. Grillitsch, M.; Nilsson, M. Innovation in peripheral regions: Do collab orations compensate for a lack of local knowledge spillovers. Ann. Reg. Sci. 2015, 54, 299-321. [CrossRef]

10. Prasad, S.; Shankar, R.; Gupta, R.; Roy, S. A TISM modeling of critical success factors of blockchain based cloud services. J. Manag. Eng. 2018, 15, 434-456. [CrossRef]

11. Tang, L.C.M.; Atkinson, B.; Zou, R.R. An entropy-based SWOT evaluation process of critical success factors for international market entry: A case study of a medium-sized consulting company. Constr. Manag. Econ. 2012, 30, 821-834. [CrossRef]

12. Abdel-Basset, M.; Mohamed, M.; Smarandache, F. An extension of neutrosophic AHP-SWOT analysis for strategic planning and decision-making. Symmetry 2018, 10, 116. [CrossRef]

13. Della Corte, V. Innovation through coopetition: Future directions and new challenges. JOItmC $2018,4,47$. [CrossRef]

14. Čirjevskis, A. The role of dynamic capabilities as drivers of business model innovation in mergers and acquisitions of technology-advanced firms. JOItmC 2019, 5, 12. [CrossRef]

15. Kang, D.; Jang, W.; Kim, Y.; Jeon, J. Comparing national innovation system among the USA, Japan, and Finland to improve Korean deliberation organization for national science and technology policy. JOItmC 2019, 5, 82. [CrossRef]

16. Mikyoung, L.; Marko, M.; Boyoung, K. Critical factors affecting sustainable success of social service systems. Entropy 2019, 5, 77.

17. Juhyeok, P.; Eungdo, K.; Kwangsoo, S. Developing an evaluation framework for selecting optimal medical devices. JOItmC 2019, 5, 64.

18. Lee, J.; Sung, T.E.; Kim, E.; Shin, K. Evaluating determinant priority of license fee in biotech industry. JOItmC 2018, 4, 30. [CrossRef]

19. Qian, W.X.; Zuo, X.J.; Chen, Y.D.; Ye, M.; Fang, Z.; Yang, F. The environmental evaluation of substation based on the fuzzy analytic hierarchy process. IOP Conf. Ser. Earth Environ. Sci. 2018, 121, 042006. [CrossRef]

20. Lin, T.T.; Hsu, S.-Y.; Chang, C.-C. Evaluation of decision-making for the optimal value of sustainable enterprise development under global 100 index thinking. Sustainability 2019, 11, 1106. [CrossRef] 
21. Dirpan, A. Combining an analytic hierarchy process and TOPSIS for selecting postharvest technology method for selayar citrus in Indonesia. IOP Conf. Ser. Earth Environ. Sci. 2018, 156, 012031. [CrossRef]

22. Dabrowski, K.; Skrzypek, K. Application of fuzzy analytic hierarchy process to building research teams. Manag. Syst. Prod. Eng. 2018, 21,7-11. [CrossRef]

23. Wojtaszek, H.; Miciuła, I. Analysis of factors giving the opportunity for implementation of innovations on the example of manufacturing enterprises in the Silesian province. Sustainability 2019, 11, 5850. [CrossRef]

24. Prasetya, J.D.; Ambariyanto; Supriharyono; Purwanti, F. Hierarchical synthesis of coastal ecosystem health indicators at Karimunjawa national Marine Park. IOP Conf. Ser. Earth Environ. Sci. 2018, 116, 012094. [CrossRef]

25. Gupta, V. Comparative performance of contradictory and non-contradictory judgement matrices in AHP under qualitative and quantitative metrics. Int. J. Decis. Support Syst. Technol. (IJDSST) 2018, 10, 21-38. [CrossRef]

26. Xu, Z.; Zhao, H. A method for fuzzy multi-attribute decision making with preference information in the form of fuzzy reciprocal judgement matrix. Fuzzy Syst. Math. 2004, 18, 115-121.

27. Jana, J.; Roy, S.K. Dual hesitant fuzzy matrix games: Based on new similarity measure. Soft Comput. 2019, 23, 8873-8886. [CrossRef]

28. Lukkarinen, J.; Berg, A.; Salo, M.; Tainio, P.; Alhola, K.; Antikainen, R. An intermediary approach to technological innovation systems (TIS)-The case of the cleantech sector in Finland. Environ. Innov. Soc. Transit. 2018, 26, 136-146. [CrossRef]

29. Bagheri, M.; Mitchelmore, S.; Bamiatzi, V.; Nikolopoulos, K. Internationalization orientation in SMEs: The mediating role of technological innovation. J. Int. Manag. 2019, 25, 121-139. [CrossRef]

30. Fan, G.; Zhong, D.; Yan, F.; Yue, P. A hybrid fuzzy evaluation method for curtain grouting efficiency assessment based on an AHP method extended by D numbers. Expert Syst. Appl. 2016, 44, 289-303. [CrossRef]

31. Tavana, M.; Zareinejad, M.; Di Caprio, D.; Kaviani, M.A. An integrated intuitionistic fuzzy AHP and SWOT method for outsourcing reverse logistics. Appl. Soft Comput. 2016, 40, 544-557. [CrossRef]

32. Huang, Y.; Porter, A.L.; Cunningham, S.W.; Robinson, D.K.R.; Liu, J.; Zhu, D. A technology delivery system for characterizing the supply side of technology emergence: Illustrated for big data \& analytics. Technol. Forecast. Soc. Chang. 2018, 130, 165-176.

33. González-Blanco, J.; Coca-Pérez, J.L.; Guisado-González, M. Relations between technological and non-technological innovations in the service sector. Serv. Ind. J. 2019, 39, 134-153. [CrossRef]

34. Nguyen, B.; Melewar, T.C.; Japutra, A.; Han, S.H.; Chen, C.-H.S.; Yu, X. An investigation of the corporate identity construct in China: Managerial evidence from the high technology industry. J. Mark. 2018, 24, 779-800. [CrossRef]

35. Buenechea-Elberdin, M.; Kianto, A.; Sáenz, J. Intellectual capital drivers of product and managerial innovation in high-tech and low-tech firms. R D Manag. 2018, 48, 290-307. [CrossRef]

36. de Kruijff, J.T.; Hurkens, C.A.J.; de Kok, T.G. Integer programming models for mid-term production planning for high-tech low-volume supply chains. Eur. J. Oper. Res. 2018, 269, 984-997. [CrossRef]

37. Torres, R.; Sidorova, A.; Jones, M.C. Enabling firm performance through business intelligence and analytics: A dynamic capabilities perspective. Inf. Manag. 2018, 55, 822-839. [CrossRef]

38. Lee, J.; Ko, S.J.; Seifrid, M.; Lee, H.; McDowell, C.; Luginbuhl, B.R.; Karki, A.; Cho, K.; Nguyen, T.; Bazan, G.C. Design of nonfullerene acceptors with near-infrared light absorption capabilities. Adv. Energy Mater. 2018, 8, 1801209. [CrossRef]

39. Manello, A.; Calabrese, G. The influence of reputation on supplier selection: An empirical study of the European automotive industry. JPSM 2019, 25, 69-77. [CrossRef]

40. Amarakoon, U.; Weerawardena, J.; Verreynne, M.L. Learning capabilities, human resource management innovation and competitive advantage. JHRM 2018, 29, 1736-1766. [CrossRef]

41. Kungl, G.; Geels, F.W. Sequence and alignment of external pressures in industry destabilisation: Understanding the downfall of incumbent utilities in the German energy transition (1998-2015). Environ. Innov. Soc. Transit. 2018, 26, 78-100. [CrossRef]

42. Aziz, A.; Oo, A.T.; Stojcevski, A. Frequency regulation capabilities in wind power plant. Sustain. Energy Technol. Assess. 2018, 26, 47-76. [CrossRef] 
43. Forkmann, S.; Henneberg, S.C.; Mitrega, M. Capabilities in business relationships and networks: Research recommendations and directions. Ind. Mark. Manag. 2018, 74, 4-26. [CrossRef]

44. Gao, P.; Song, Y.; Liu, J.; Liu, C.S. Study on the coupling development between higher education and high-tech industry innovation in China: An empirical study from Shandong Province. J. Soc. Sci. Humanit. 2018, 1, 50-54.

45. Chen, H.; He, P.; Zhang, C.X.; Liu, Q. Efficiency of technological innovation in China's hightech industry based on DEA method. J. Interdiscip. Math. 2017, 20, 1493-1496. [CrossRef]

46. Zuo, L.; Zhou, J.; Wei, F. Study on the innovation incubation ability evaluation of high technology industry in China from the perspective of value-chain. Open J. Soc. Sci. 2018, 6, 247. [CrossRef]

47. Cai, J.G.; Zhang, Y.; Sun, O.W.; Yang, Q.Q. Comprehensive evaluation and construction of drought resistance index system in Hydrangea macrophylla. Ying Yong Sheng Tai Xue Bao J. Appl. Ecol. 2018, $29,3175$.

48. Wang, G.D.; Li, N.; Xiong, X.H.; Chong, Q.; Zhou, L.; Lu, S.W. 3D level comprehensive evaluation of hole quality in drilling carbon fiber-reinforced plastics. Int. J. Adv. Manuf. Technol. 2017, 93, 2433-2445. [CrossRef]

49. Guo, Q.H.; Li, Q.; Wang, J.; Liu, M.; Wang, Y.; Chen, Z.; Ye, Y.; Guan, Q.; Zhou, Y. A comprehensive evaluation of clinical efficacy and safety of celecoxib in combination with chemotherapy in metastatic or postoperative recurrent gastric cancer patients: A preliminary, three-center, clinical trial study. Medicine 2019, 98, e16234. [CrossRef]

50. Eubank, B.H.; Mohtadi, N.G.; Lafave, M.R.; Wiley, J.P.; Bois, A.J.; Boorman, R.S.; Sheps, D.M. Using the modified Delphi method to establish clinical consensus for the diagnosis and treatment of patients with rotator cuff pathology. BMC Med. Res. Methodol. 2016, 16, 56. [CrossRef]

51. Yan, X.; Chen, M.; Chen, M.-Y. Coupling and coordination development of Australian energy, economy, and ecological environment systems from 2007 to 2016. Sustainability 2019, 11, 6568. [CrossRef]

52. Ameyaw, E.E.; Hu, Y.; Shan, M.; Chan, A.P.C.; Le, Y. Application of Delphi method in construction engineering and management research: A quantitative perspective. J. Civ. Eng. Manag. 2016, 22, 991-1000. [CrossRef]

(C) 2020 by the authors. Licensee MDPI, Basel, Switzerland. This article is an open access article distributed under the terms and conditions of the Creative Commons Attribution (CC BY) license (http://creativecommons.org/licenses/by/4.0/). 